\title{
The celebrification of farmers: celebrity and the new politics of farming
}

Article

Accepted Version

Phillipov, M. and Goodman, M. K. (2017) The celebrification of farmers: celebrity and the new politics of farming. Celebrity Studies, 8 (2). pp. 346-350. ISSN 1939-2400 doi:

https://doi.org/10.1080/19392397.2017.1311629 Available at https://centaur.reading.ac.uk/71621/

It is advisable to refer to the publisher's version if you intend to cite from the work. See Guidance on citing.

To link to this article DOI: http://dx.doi.org/10.1080/19392397.2017.1311629

Publisher: Informa UK Limited

All outputs in CentAUR are protected by Intellectual Property Rights law, including copyright law. Copyright and IPR is retained by the creators or other copyright holders. Terms and conditions for use of this material are defined in the End User Agreement.

\section{www.reading.ac.uk/centaur}

\section{CentAUR}

Central Archive at the University of Reading

Reading's research outputs online 


\section{The celebrification of farmers: Celebrity and the new politics of farming}

\section{Forthcoming in Celebrity Studies}

Michelle Phillipov

Journalism, Media and Communications

School of Social Sciences, University of Tasmania

Michael K. Goodman

Geography and Environmental Science

University of Reading

"Farmers are the real rock stars," says American celebrity chef Mario Batali (2014, p. 9) in the opening line of his tenth and most recent cookbook, America farm to table: simple, delicious recipes celebrating local farmers. For Batali (2014, p. 10), the popular influence of the "celebrity chef" should be replaced by that of the "celebrity farmer", a figure with much greater potential to change not only how we cook at home, but also the food system as a whole. A few months after Batali's book was published, secretary of the California Department of Food and Agriculture, Karen Barrett Ross, was reported as saying that it is her "dream to make farmers [like] rock stars", as has happened with wine makers and celebrity chefs (Potter 2015).

These comparisons of farmers to rock stars highlight significant changes to the public profile of farmers and farming in recent years. While over the past few decades, farmers have enjoyed less cultural prominence than other food industry figures in the global North - most notably, celebrity chefs and food personalities such as Michael Pollan - they are now undergoing similar processes of celebrification. We can see this in the emergence of internationallyrecognised farmers such as Joel Salatin and José Bové as the public faces of opposition to industrial food production - Salatin through his defiant eco-local livestock production and Bové through his fierce anti-corporate food activism. We can also see it in more 'everyday' 
practices, such as the rise of farmers' markets, which are enjoying growth in part due to the opportunities they offer consumers to meet and 'connect' with food producers (e.g. Kirwan, 2004). Farmers' names are increasingly appearing on the restaurant menus of produce-driven eateries or on name-branded products such as those of UK's farmer-turned-politician Wilfred Emmanuel-Jones, whose Black Farmer label is sold by major supermarkets. Small retailers and major supermarkets alike are placing farmers centre stage through in-store, 'integrated' and traditional advertising campaigns (Johnston et al, 2009; Phillipov, 2016b). Cookbooks featuring stories of farmers and their produce are now commonplace. Primetime television cooking shows - from Hairy Bikers (US) to Gourmet Farmer (Australia) to Farmhouse Rules (US) regularly include visits to farmers to collect ingredients and showcase their stories and production practices.

The increasing prominence of farmers in media and popular culture can be seen in part as a reflection of the growth of alternative and sustainable food practices (see Goodman, DuPuis and Goodman 2012), in which a sense of connection to one's food and how it is produced is seen as essential for combatting the anonymity of industrial food production. The figure of the celebrity farmer works to provide us with (emplaced) "Food from Somewhere" - rather than (industrial) "Food from Nowhere" (Campbell, 2009, p. 318) - that is, food which is 'placed', authentic, trustworthy and knowable. It is also a reflection of the currency of celebrity as a model for the enactment of a range of contemporary public identities (Turner 2004) and activist politics more broadly (Goodman et al., 2016; Goodman and Littler, 2013; Brockington, 2014; Richey, 2015). In the food space, this includes not just already well known "food celebrities" such as celebrity chefs and entertainment celebrities (Johnston and Goodman 2015, 
p. 206). It also now includes 'ordinary' people, such as farmers, who do not necessarily have large public profiles, but whose activities and values become meaningful for particular audience and consumer niches - most commonly for the urban, middle class "foodies" who are the primary audience for food-related media texts (Johnston and Bauman, 2010).

These texts vary significantly in their generic conventions, political economies and production practices, but they share a number of similarities in how they represent farmers, and do so in three key ways that embody many of the qualities associated with celebrity and its processes. First, whether in cookbooks, advertising and promotional articles, or in television cooking shows, representations tend to foreground the identity and persona of the farmer. Specifically, they tend to feature farmers' personal stories of how they came to farming, what the business means to them and their families, and how their production practices reflect a kind of idyllic, unalienated labour in which the farmer is deeply invested (Phillipov 2016a). In this, performance and performativity are front and centre to these new forms of celebrity farmer mediation, which are as much about the production of affective capitalism (e.g. Illouz 2007) as alternative food networks.

Second, with their focus on links between the personal and the professional, these representations adopt what Marshall (2014, p. 158) calls the "public/private/intimate of celebrity discourse", in which farmers' personal lives and narratives are central to their professional identities. While this may be just one more example of the discursive bleeding of celebrity into more and more aspects of contemporary life, it also has the potential to offer insight into contemporary processes of celebrity construction and the emerging role of 
celebrity in shaping alternative food systems and food practices. What does this celebrification of farmers mean for our understanding of celebrity? What does it mean for the farmers themselves as newly christened media and food celebrities?

Third, the farmers most likely to appear in media are typically small-scale farmers operating outside of dominant food systems, and in particular, outside of dominant systems of supermarket retail (Phillipov 2016c). Their depictions in popular media culture are another example of the expansion and proliferation of the "public self" in response to the changing demands of contemporary work economies and social networks (Marshall 2014, p. 154). Farmers are increasingly part of a long line of professionals who now need to "sell themselves" in a competitive marketplace by adopting the strategies characteristic of the presentational forms of media associated with celebrity culture (see Marshall 2014, p. 158).

This has given farmers in the alternative food sector opportunities to promote themselves and their businesses in new ways. Whether it is face-to-face interactions at farmers' markets, appearances on television cooking shows or profiles in cookbooks, the 'story' behind the food and (consumer's perception of) the idyllic nature of a life devoted to food production can be used to invite affective investments in the politics of food and food production. If, as Marshall (1997, p. 199) argues, celebrities are "means and methods of housing affective power", this power is mobilised by and through these representations in ways that present farmers' food work, and their resulting food products, as both desirable and aspirational. These figures have become powerful voices in debates about so-called 'good food', i.e. what we should and should not eat (see Goodman et al., 2010), much like celebrity chefs before them. The critical 
question is: what does the rise of the celebrity farmer mean for how notions of 'good' food -a contentious and politicised topic at the best of times - are constructed through media, and understood and acted on by audiences? How might the affective power of celebrity farmer “talking labels" (see Barnes 2014) offer particular "technologies" (Foucault, 2003) for individual and food systems governance?

But while these characteristics of desirability may offer promotional opportunities for some farmers as niche marketing strategies, the celebrification of farming, like all forms of celebrification, necessitates attention to questions of power and inequality (Johnston and Goodman 2015). ${ }^{1}$ It is often the case that farmers' "celebrity" is mediated by other celebrity identities, most frequently that of the celebrity chef. As a result, these questions of inequality relate not just to the types of food being promoted in these texts, but also to the level of power the farmers themselves may possess. Given that farmers are typically the subjects of cookbooks, not their authors, and the guests of television cooking shows, not their hosts, they are typically engaging in representations over which they do not necessarily have controland in which their needs are not necessarily the same those of the media producers and publishers.

The representation of farmers in media and cultural texts may reflect the desires of the urban middle classes to reconnect with their food and its producers, but the commercial viability of

\footnotetext{
${ }^{1}$ Although it is outside the scope of this paper, we acknowledge that attention is needed not only to the power and inequality experienced by farmers and food celebrities, but also to that experienced by animals that are used as resources in farming, and whose labour farming celebrity often serves to erase (see, for example, Cole 2011).
} 
these texts frequently hinges on the extent to which they appeal to urban, middle class fantasies of food production and consumption (Peace 2011). These do not necessarily reflect the realities of farming for the farmers who are depicted in these texts. The hard work, the long hours, the precariousness of small farms are often side-lined in favour of a constructed idyllism that potentially obscures more than it reveals about the nature of contemporary food production. Similarly, given the often 'gourmet' nature of the foods on offer, they are often affordable to only those of more extensive economic means. Thus, the virtual food economies created by celebrity farmers have worrying questions not just of inequality and power but also, as critical food scholarship continues to point out, food justice (e.g. Alkon and Agyeman, 2011; Cadieux and Slocum, 2015).

Consequently, while celebrity may be linked with power, not all celebrity figures - or their audiences - are empowered equally. Further research is still needed to determine the ways in which farmers are empowered or disempowered through these new media environments, how these media activities are impacting on their food production and business practices, and how practices of audience engagement and food systems advocacy are enabled and constrained by these practices of celebrity and celebrification. Overall, a great deal of work is still needed to explore this new cultural politics of celebrity farming.

\section{References}

Alkon, A., \& Agyeman, J., 2011. Cultivating food justice: race, class and sustainability. London: MIT Press. 
Barnes, C., 2014. Mediating good food and moments of possibility with Jamie Oliver:

Problematising celebrity chefs as talking labels. Geoforum. Online first:

http://www.sciencedirect.com/science/article/pii/S0016718514001985.

Batali, M., 2014. America farm to table: simple, delicious recipes celebrating local farmers. New York:

Grand Central Life \& Style.

Brockington, D., 2014. Celebrity advocacy and international development. London: Routledge.

Cadieux, K., \& Slocum, R., 2015. What does it mean to do food justice? Journal of Political Ecology, 22, 1-26.

Campbell, H., 2009. Breaking new ground in food regime theory: corporate environmentalism, ecological feedbacks and the 'food from somewhere' regime? Agriculture and Human Values, 26, 309-319.

Cole, M., 2011. From 'animal machines' to 'happy meat'? Foucault's ideas of disciplinary and pastoral power applied to 'animal-centred' welfare discourse. Animals, 1(1), 83-101.

Foucault, M., 2003. Technologies of the self. In: P. Rabinow \& N. Rose, eds. The essential Foucault: selections from the essential works of Foucault 1954-1984. New York: The New Press, 144-69.

Goodman, M., \& Littler, J., 2013. Celebrity Ecologies: Introduction. Celebrity Studies, 4, 269-275.

Goodman, M., Maye, D., \& Holloway, L., 2010. Ethical Foodscapes?: Premises, Promises and Possibilities. Environment and Planning A, 42, 1782-1796.

Goodman, D., DuPuis, E.M. and Goodman, M.K., 2012. Alternative food networks: knowledge, place and politics. London: Routledge. 
Goodman, M., Littler, J., Brockington, D., \& Boykoff, M., 2016. Spectacular

Environmentalisms: Media, Knowledge and the Framing of Ecological Politics.

Environmental Communication: A Journal of Nature and Culture.

Illouz, E. (2007). Cold intimacies: The making of emotional capitalism. Cambridge: Polity Press.

Johnston, J., \& Baumann, S., 2010. Foodies: Democracy and Distinction in the Gourmet Foodscape.

London: Routledge.

Johnston, J. and Goodman, M.K., 2015. Spectacular foodscapes: food celebrities and the politics of lifestyle mediation in an age of inequality. Food, Culture $\mathcal{E}$ Society, 18 (2), 205-222.

Johnston, J., Biro, A., \& MacKendrick, N., 2009. Lost in the supermarket: the corporate-organic foodscape and the struggle for food democracy. Antipode, 41, 509-532.

Kirwan, J., 2004. Alternative strategies in the UK agro-food system: interrogating the alterity of farmers' markets. Sociologia Ruralis, 44, 395-415.

Marshall, P.D., 2014. Persona studies: mapping the proliferation of the public self. Journalism, $15(2), 153-170$.

Marshall, P.D., 1997. Celebrity and power: fame in contemporary culture. Minneapolis: University of Minnesota Press.

Peace, A., 2011. Barossa dreaming: imagining place and constituting cuisine in contemporary Australia. Anthropological Forum, 21 (1), 23-42.

Phillipov, M., 2016a. Escaping to the country: media, nostalgia and the new food industries. Popular Communication, 14 (2), 111-122.

Phillipov, M., 2016b. 'Helping Australia Grow': supermarkets, television cooking shows, and the strategic manufacture of consumer trust. Agriculture and Human Values, 33 (3), 587596. 
Phillipov, M., 2016c. Using media to promote artisan food and beverages: insights from the television industry. British Food Journal, 118 (3), 588-602.

Potter, L., 2015. California ag secretary: farmers should have rock star status of chefs, wine makers. Kearney Hub, 20 January, http://www.kearneyhub.com/news/local/california-agsecretary-farmers-should-have-rock-star-status-of/article 0d5e96c8-7490-53eb-bd45$\underline{6 \mathrm{cb} 88161178 \mathrm{c} \cdot \mathrm{html}}$.

Richey, L., 2015. Celebrity humanitarianism and north-south relations: politics, place and power. Milton Park: Routledge.

Turner, G., 2004. Understanding celebrity. London: Sage. 